\title{
Between The Acts: O Ato Final D(IAG)RAMÁTICO-ESCRITURAL DE VIRGINIA WOOLF
}

\author{
Between the acts: Virginia Woolf's d(iag)ramatic- \\ scriptural final act
}

\author{
Soraya Ferreira Alves*
}

Between the Acts (1941) é o último romance de Virginia Woolf. Enquanto escrevia, ela vivia os horrores da Segunda Guerra Mundial, acompanhada de mais uma de suas crises de loucura. De acordo com Lehmann (1989), amigo e autor de uma pequena biografia da autora, ao terminar o livro e relê-lo, Woolf considera-o produto de sua doença e opta por não revisá-lo, chegando à conclusão que as crises já haviam afetado-lhe de tal forma que não conseguiria mais escrever.

Assim, decide dar fim à sua vida afogando-se no Rio Ouse, perto de sua casa em Sussex, em 1941.

Between the Acts, no entanto, pode ser considerado bem mais do que um produto da loucura, mas, se realmente o for, como acreditava Woolf, esta só contribuiu para que suas ideias e criatividade fluíssem de forma tão intensa a ponto de conseguir expressar toda a força de uma escritura elaborada e reelaborada ao longo de toda a sua obra.

Woolf passou mais de 20 anos e vários romances usando e aprimorando a técnica do fluxo da consciência ${ }^{1}$ e relativisando o tempo, como em Mrs. Dalloway (1925), que narra um dia na vida de Clarissa Dalloway, mas, através do pensamentos em flash-back dos personagens, conta a história da vida de todos eles, principalmente um momento em

- Universidade de Brasília.

${ }^{1}$ Termo cunhado por William James em Principles of Psychology, 1890, indica o fluxo contínuo do pensamento ao estabelecer relações entre eventos presentes e passados, em atividade sempre contínua e associativa e marcado por influências internas e externas. É usado para definir técnica narrativa literária, muito difundida em obras de autores da modernidade, ao representar o movimento ininterrupto e multisígnico de sentimentos e impressões vivenciadas pelas personagens que comporiam o processo da consciência. 
comum no passado que define seus destinos; e em Orlando (1929), que conta a história de um personagem que atravessa os séculos, representando toda a história de uma família e que vive metade da vida como homem e depois transforma-se em mulher; porém, é em Between the Acts que Woolf concentra todas as suas experiências escriturais.

Pretende-se, com este trabalho, mostrar como Virginia Woolf cria uma escritura diagramática que faz uso de técnicas narrativas que remetem ao tempo, ao processo e movimento da memória, à medida que promove a interação entre o verbal e o não verbal. A fim de elucidar tal prática, será tomada como base teórica a semiótica de Charles S. Peirce (1839-1914), uma vez que, como explicam Santaella e Nöth (1999, p. 59), "as variadas classificações apresentadas por ele [Peirce] fornecem uma gama muito sutil de ferramentas analíticas que nos permitem penetrar nos interiores dos signos visualizando sua natureza".

De acordo com Santaella (2002, p. 5), a semiose, ou cadeia de significado, é constituída pela relação triádica e dinâmica entre o signo, o objeto e o interpretante, sendo que o signo é um conteúdo apreendido pelos sentidos, pela imaginação, pela memória, pelo pensamento e liga o objeto (aquilo que ele, signo, representa ou substitui) a um interpretante (efeito que o signo produz no intérprete, ou seja, a potencialidade do signo em sugerir, significar, mas que já está inscrita no próprio signo). A forma como o signo representa o seu objeto pode ser classificada em ícone, índice e símbolo.

De acordo com Santaella e Nöth (1999, p. 60), Peirce dividiu o ícone em vários níveis e subníveis, estipulando que são as relações de similaridade que o constituem. "Peirce dividiu os ícones em ícone puro e signos icônicos ou hipoícones". O nível do ícone puro (e suas subdivisões) tem importância fundamental, como ainda explicam os autores (SANTAELLA; NÖTH, 1999, p. 62), "na fruição estética, de poemas principalmente, e das formas não representativas, puramente qualitativas, presentes na chamada arte abstrata." Já os hipoícones, diferentemente do nível do ícone puro, agem como signos porque representam algo e são governados pela similaridade e relações de comparação. Como explica Santaella (2002), os subníveis dos hipoícones são a imagem, que reúne os ícones que mantêm uma relação de analogia qualitativa entre a representação e o referente, como desenho, foto, pintura figurativa que retomam as qualidades formais de seu referente, tais como formas, cores, proporções que permitem reconhecê-los; o diagrama, que utiliza uma analogia de relação interna com o objeto, ou seja, relação existente entre as partes de uma coisa em suas próprias partes, tal como o organograma de uma empresa, uma tabela, um gráfico; e a metáfora, que trabalha a partir de um paralelismo qualitativo entre o que o signo representa e algo diverso deste.

Quando se afirma, portanto, que Woolf cria um diagrama escritural, pretende-se mostrar que as relações de similaridade se darão tanto em um plano macro, como a técnica narrativa do fluxo da consciência 
e da relativização do tempo, bem como em um plano micro, que é o da estrutura de frases e da repetição de palavras, que estabelecem relações internas e assim representam o próprio movimento da mente, como se verificará nos exemplos que serão expostos ao longo do texto.

Pode-se fazer um paralelo com os estudos de Santaella (2002, p. 327 ) sobre a linguagem (matriz) verbal e suas modalidades, nos quais denomina esse tipo de narrativa de espacial, mais especificamente de espacialização icônica, pois "há uma relação de semelhança entre o espaço daquilo que é narrado e o espaço interno desenhado pelos diagramas relacionais das seqüências narrativas".

Seguindo-se com as formas de representação do signo em relação ao seu objeto, chega-se ao índice que é um tipo de representação que se dá pelas marcas causadas pelo objeto, pois, como explica Santaella (2002, p. 6),

estabelece uma relação de fato (concreta) com o objeto, em virtude de ser afetado por ele. $O$ índice aponta para o seu objeto por ser uma parte deste. [...] As possibilidades interpretativas são fechadas. Por ser uma relação dual, na qual signo e objeto estão conectados, o potencial interpretativo dos índices se reduz à ligação existencial de um signo indicando seu objeto.

Já o símbolo opera por meio de uma lei, uma convenção, como explicam Santaella e Nöth (1999, p. 63), "a relação entre o símbolo e seu objeto se dá através de uma mediação, normalmente uma associação de idéias [...] hábito ou lei adquirida que fará com que o símbolo seja tomado como representativo de algo diferente dele".

Peirce definiu outras classificações, como as referentes à relação do signo com ele mesmo (quali-signo; sin-signo; legi-signo) e do signo em relação ao interpretante (rema; dissente; argumento). Neste trabalho, porém, vamos nos ater à classificação da relação do signo com o objeto, pois esta suprirá as bases teóricas necessárias para a aplicação em nossa análise.

Em Between the Acts, Woolf continua transitando pela história ao condensar as mais variadas épocas em apenas um dia na vida dos representantes da comunidade de um vilarejo que se prepara para a encenação de uma pequena peça sobre os principais eventos da história do país. Misturando épocas, personagens do passado e do presente, vidas, falas e pensamentos que se cruzam, Virginia Woolf intensifica ainda mais sua representação do tempo e fluxo da mente.

Alguns eventos descritos antes da peça anunciam o processo que alcançará seu clímax durante a performance. Logo no início, Mrs. Swithin, uma conhecida senhora do povoado, decide retomar sua leitura favorita Outline of History - que conta, condensadamente, a história da Inglaterra desde a pré-história até o tempo presente e, ao fazê-lo, mistura certos fatos com os atos de sua própria vida cotidiana. 
[...] [she] had spent the hours between three and five thinking of rhododendron forests in Piccadilly [...] (WOOLF, 1992, p. 8).

No trecho que assim se inicia, passado e presente estão embaralhados pela imaginação de Mrs. Swithin que vê rhododendron forests (florestas de azaleias) em Piccadilly, ou que confunde o ruído de um animal pré-histórico prestes a derrubar uma árvore, com o abrir da porta por sua empregada.

O tempo relativo da mente é colocado em oposição ao tempo do relógio, quando o narrador diz que em tempo real ela havia levado cinco segundos para perceber que Grace, a criada, não era um animal pré-histórico, mas que em sua mente, o tempo havia sido infinitamente maior: "It took her five seconds in actual time, in mind time ever so much longer..." (WOOLF, 1992, p. 8).

Uma outra sequência tem início quando a personagem Isa, significativa e metaforicamente, mira-se em um espelho de três faces, no qual pode ver "three separate versions of her heavy, yet handsome, face..." (WOOLF, 1992, p. 11): três versões diferentes, três sentimentos diferentes, como explica: o amor por um fazendeiro da comunidade, o amor por seu marido e o amor por seu filho. Todos postos em conflito, simultaneamente, naquele momento, pois vê objetos e paisagens que a fazem lembrar dos três.

A sequência de atos banais da vida cotidiana - pentear-se diante do espelho, murmurar um trecho de um poema, telefonar para uma peixaria - deflagra uma outra sequência, nada banal, que se manifesta escrituralmente, desocultando um feixe de significados surpreendentes:

Where we know not, where we go not, neither know nor care," she hummed. Flying, rushing through the ambient, incandescent, summer silent..."

The rhyme was "air." She put down her brush. She took up the telephone.

"Three, four, eight, Pyecombe," she said.

"Mrs. Oliver speaking ... What fish have you this morning? Cod? Halibut? Sole? Plaice?"

"There to lose what binds us here," she murmured. "Soles. Filleted. In time for lunch please," she said aloud. "With a feather, a blue feather ... flying mounting through the air ... there to lose what binds us here ..." The words weren't worth writing in the book bound like an account book in case Giles suspected (WOOLF, 1992, p. 12$)^{2}$.

A palavra combe, dentro de Pyecombe, remete ao ato de Isa pentear os cabelos, sendo essa a palavra que aparece logo no início da cena que narra o momento em esta que se olha ao espelho: "Mrs. Giles Oliver drew

${ }^{2}$ Os grifos são meus. 
the comb through the thick tangle of her hair...", o que faz pensar na associação de ideias que a princípio parecia tão estranha. Logo depois vemos sole, o peixe, como anagrama de lose, palavra que se torna componente do poema murmurado por Isa. E plaice, também um peixe, vai encontrar seu semelhante em please.

Além disso, sole também irá ecoar no pensamento de Isa na palavra soul:

A foolish, flattering lady, pausing on the threshold of what she once called "the heart of the house," the threshold of the library, once said: "Next to the kitchen, the library's always the nicest room in the house." Then she added, stepping across the threshold: "Books are the mirrors of the soul."

In this case a tarnished, a spotted soul. For as the train took over three hours to reach this remote village in the very heart of England, no one ventured so long a journey, without starving of possible mind-hunger, without buying a book on a bookstall. Thus the mirror that reflected the soul sublime, reflected also the soul bored (WOOLF, 1992, p. 12-3) ${ }^{3}$.

A frase "Books are the mirrors of the soul" convida a uma leitura espelhada: "Mirrors are the books of the soul". De fato, mais adiante, essa frase tomará a seguinte configuração: "The mirrors of the soul books were." - um palíndromo mais de ideias do que de letras. No final da sequência, lêse: "The words were like the first peal of a chime of bells. As the first peals, you hear the second; as the second peals, you hear the third". Não é diferente o processo da cadeia de palavras e eventos da memória e da história. Vê-se, aqui, como as propriedades icônicas tanto sonoras como pictóricas das palavras sobrepõem-se ao seu aspecto simbólico, convencional e assim permitem que seja criado um diagrama do fluxo da consciência. Nesse caso, assumindo características indiciais, pois representa a força da própria coisa, seu objeto, o próprio movimento do pensamento.

Nessa obra, Woolf aprimora recursos que começara a desenvolver em obras anteriores, como palavras que parecem sair umas de dentro das outras, ou da repetição que sutilmente se renova. Além dos exemplos apresentados acima, há um efeito comum a toda a narrativa em que palavras, apresentando semelhanças visuais ou sonoras, são colocadas em cadeia, como se ressoassem, ecoassem, ou se transformassem em outras, como se observa nas seguintes frases:

- She came in like a swan swimming its way (p. 5);

- The Afghan hound bounding and bouncing among the flowers (p. 10);

- Their voices impetuously, impatiently, protestingly came across

${ }^{3} I d$. 
the hall (p. 25);

- That was the shock. After that, the rock was raced round, embraced (p. 25);

- At that the fleet of boat-shaped bodies paused; poised; equipped (p. 28);

- He had finished his fish (p. 32);

- Outwardly she was swarthy, sturdy and thick set; strode about the fields in a smock frock (p. 37);

- Sitting on the bed he heard her sing, swinging her little legs, 'Come and see my sea weeds (p. 44);

- Resembled an uncouth, nocturnal animal (p. 58);

- Where the great pear tree spread... (p. 93).

As palavras são ordenadas de modo a reproduzirem, iconicamente, o processo associativo da memória, criando uma metalinguagem que implicitamente rege a configuração sonora das frases ao justapor elementos semelhantes que se unem para a montagem de uma forma mais abrangente, no caso, o próprio fluxo da consciência.

Uma outra explicação metalinguística a este recurso, dada no início da obra, poderia estar na descrição da conversa de duas babás, que é feita de "rolling words, like sweets on their tongues; which, as they thinned to transparency, gave off pink, green and sweetness." (WOOLF, 1992, p. 9). Da mesma forma, as sequências de palavras, que "rolam" de uma para a outra e, no processo, se modificam.

Gillian Beer, no texto de Introdução ao romance, observa esse efeito se repetindo durante toda a obra: "In this book, access to halfconsciousness, communal and individual, is given by the anarchic neatness of rhyme, which pins together the unlike, making the ear the arbiter of signification." (BEER, 1992, p. xvii). O contraponto entre a palavra escrita e a palavra falada explora o modo como as figuras sonoras aderem umas às outras, fazendo um jogo de remitências que amplia o significado.

Com relação ao jogo sonoro em Between the Acts, conviria ainda uma vez mais citar a análise de Beer, que introduz também uma outra problemática quanto à iconicidade na escritura woolfiana:

Words mean differently - sound differently - as they are spoken into new experiences. This novel makes clear that though things are said many times they never mean quite the same. As a result, though opposites alternate they never pair simply as disappointment, as slack recurrence. It is not enough, as some recent critics have done, to note alternation as if the matter ended there. Language is capable always of tugging the reader through into unforeseen feeling (BEER, 1992, p. Xxi).

Se a linguagem é capaz de arrastar o leitor por sentimentos imprevisíveis, ela o faz por meio da intersemiose, pela interação entre os signos, que estão sempre estabelecendo novas e inesgotáveis associações. 
Começada a peça, o terraço de uma antiga e tradicional fazenda é transformado em palco; à sua frente, a plateia espalha-se pelo gramado. Miss La Trobe, a diretora, pretenciosamente intenciona contar toda a história britânica, desde a antiguidade até o tempo presente. Entre fofocas e conversas, confundem-se pessoas e personagens, como, por exemplo, na entrada da "Rainha Elizabeth", interpretada por Eliza Clark, dona de um armazém:

Everyone was clapping and laughing. From behind the bushes issued Queen Elizabeth - Eliza Clark, licensed to sell tobacco. Could she be Mrs. Clark of the village shop? She was splendidly made up. Her head, pearl-hung, rose from a vast ruff. Shiny satins draped her. Sixpenny brooches glared like cats' eyes and tigers' eyes; pearls looked down; her cape was made of cloth of silver - in fact swabs used to scour saucepans. She looked the age in person. And when she mounted the soap box in the centre, representing perhaps a rock in the ocean, her size made her appear gigantic. She could reach a flitch of bacon or haul a tub of oil with one sweep of her arm in the shop. For a moment she stood there, eminent, dominant, on the soap box with the blue and sailing clouds behind her. The breeze had risen (WOOLF, 1992, p. 52).

O jogo mental entre tempos e associações desenvolve-se com tal rapidez que subverte o tempo do relógio. Durante toda a encenação, porém, há longos intervalos entre um ato e outro, onde as pessoas aproveitam para comer, passear pela fazenda, conversar, enfim, passar o tempo. Mas esse passar o tempo transforma-se em passar do tempo; tanto metaforicamente, como em relação às diferentes épocas da peça que vão se seguindo, como também no sentido que as pessoas adquirem desse passar, o que as aflige, deixa nervosas, até chegarem, juntamente com o ato final, ao tempo presente. Assim, encontram-se comentários tais como o dos irmãos Mrs. Swithin e Mr. Oliver que esperam o recomeço da peça e este diz, quase sem pensar, a expressão: "Making time" (WOOLF, 1992, p. 51) ao que sua irmã responde: "Which don't exist for us... We've only the present".

No último ato, quando é apresentado o tempo presente, um intenso conflito se estabelece no palco, pois Miss La Trobe usa de recursos estratégicos para representá-lo. Primeiramente, ela prolonga o intervalo, o que faz com que as pessoas se inquietem. Para ela, esse longo intervalo já coloca a todos em contato com o tempo presente:

Miss La Trobe stood there with her eyes on her script. "After Vic." She had written, "try ten mins. Of present time. Swallows, cows, etc." She wanted to expose them, as it were, to touch them, with present-time reality. But something was going wrong with the experiment. "Reality too strong," she muttered (WOOLF, 1992, p. 107).

Chegando à parte em que se lê no programa: "Present time. 
Ourselves.", o ritmo da apresentação muda, uma vez que até então era marcado por um velho gramofone, cujo ruído se repetia incessantemente: "chuf, chuf, chuf; tick, tick, tick". E, de repente: "The tune changed; snapped; broke, jagged. Fox-trot was it? Jazz? Anyhow the rhythm kicked, reared, snapped short. What a jangle and a jingle!" (WOOLF, 1992, p. 109). Então, por de trás das árvores, figuras começam a surgir segurando espelhos das mais diferentes formas a fim de refletirem a plateia. Mas o curioso é que refletem apenas partes de cada pessoa:

Look! Out they come, from the bushes - the riff-raff. Children? Imps - elves - demons. Holding what? Tin cans? Bedroom candlesticks? Old jars? My dear, that's the cheval glass from the Rectory! And the mirror - that I lent her. My mother's. Cracked. What's the notion? Anything that's bright enough to reflect, presumably, ourselves?

Ourselves! Ourselves!

Out they leapt, jerked, skipped. Flashing, dazzling, dancing, jumping. Now old Bart ... he was caught. Now Manresa. Here a nose ... There a skirt ... Then trousers only ... Now perhaps a face ... Ourselves? But that's cruel. To snap us as we are, before we've had time to assume ... And only, too, in parts ... That's what's so distorting and upsetting and utterly unfair (WOOLF, 1992, p. 109).

Em meio a essa confusão de formas, surgem também no palco os atores que interpretaram cada época, com seus trajes característicos e proferindo fragmentos de suas falas, numa verdadeira apoteose cênica tempórica, ampliando ainda mais o sentido de simultaneidade:

... - Queen Bess; Queen Anne; and the girl in the Mall; and the Age of Reason; and Budge the policeman. Here they came. And the old man with a beard. They all appeared. What's more, each declaimed some phrase or fragment from their parts ... I am not (said one) in my perfect mind ... Another, Reason Am I ... And I? I'm the old top hat ... Home is the hunter, home from the hill ... Home? Where the miner sweats, and maiden faith is rudely strumpeted ... Sweet and low; sweet and low, wind of the western sea ... Is that a dagger that I see before me? ... The owls hoots and the ivy mocks tap-tapping on the pane ... lady I love till I die, leave thy chamber and come .... [...]

The hands of the clock had stopped at the present moment. It was now. Ourselves (WOOLF, 1992, p. 110).

Sentindo-se indignada com tal surpresa, vendo-se refletida aos pedaços, a plateia começa a dispersar-se:

Dispersed are we, the gramophone triumphed, yet lamented, 


\begin{abstract}
Dispersed are we..."
The wheels scurred on the gravel. The cars drove off. The gramophone gurgled Unity - Dispersity. It gurgled Un ... dis ... And ceased (WOOLF, 1992, p. 117-9).
\end{abstract}

Esse recorte metonímico das formas se reflete também na estrutura das falas das personagens, que são muitas vezes fragmentadas, interrompidas, pois a indicação de quem e como fala, são colocadas no meio, e não no início ou no fim destas. Essas estruturas ajudam a montar um diagrama complexo, onde um recurso ou técnica da narrativa não ocupa um lugar solitário, mas está intimamente ligado às partes que compõem a obra.

Essas interrupções nas falas podem também ser entendidas como uma representação icônica das próprias interrupções ocorridas durante a peça: "' $O$ ', Miss La Trobe growled behind the tree, 'the torture of these interruptions!'” (WOOLF, 1992, p. 50), devido às pessoas que chegam atrasadas, aos animais que passam pelo meio do cenário, ao barulho das cadeiras, a chuva que cai, e o vento, que leva as palavras e interrompe o fluxo das falas das personagens da peça:

All the time the villagers were passing in and out between the trees. They were singing; but only a word or two was audible "...wore ruts in the grass... built the house in the lane..." The wind blew away the connecting words of their chant, and then, as they reached the tree at the end they sang:

"To the shrine of the Saint... to the tomb... lovers... believers... we come..." (WOOLF, 1992, p. 50).

Essas quebras podem ser vistas também metaforicamente, como a interrupção de suas próprias vidas, ou de seu modo de vida, uma vez que a guerra está bem próxima e os aviões já sobrevoam sua cidade.

Um dos melhores exemplos da interrupção nas falas está na frase: “Am I,' Isa aplogized, 'interrupting?'” (WOOLF, 1992, p. 13). Representando e, ao mesmo tempo, materializando a própria interrupção.

De acordo com Madelyn Detloff, em seu ensaio Thinking Peace into Existence: The Spectacle of History in Between the Acts, esta obra deveria ser lida como: “...the last act in the drama of her life, a prelude to her suicide, her final testament against the patriarchal forces that led Europe into the Second World War" (DETLOFF, 2000, p. 403).

Ao montar um paralelismo entre o pageant e a II Guerra Mundial, Detloff aponta para traços tanto pacifistas como feministas na escritura woolfiana. A autora observa, primeiramente, a importância da data em que se passa a história, o ano de 1939, ou seja, um ano antes de ser oficialmente decretada a guerra, e argumenta que, ao invés de apresentar as consequências trágicas desta, Woolf contextualiza sua obra no verão de 1939 , quando o 
início da guerra era uma possibilidade muito forte, mas não ainda inteiramente inevitável. Incluindo vários momentos históricos e mesmo histórias pessoais vistos por ângulos diversos, e ambientando sua história pouco antes da declaração da guerra, Between the Acts abre um campo de possibilidades para os resultados do que estaria por vir. Além disso, a encenação da história Inglesa como uma sátira e não como uma tragédia, ainda segundo Detloff:

... challenges versions of history that script the onset of war as inevitable. The fatalism intimated by the unstoppable downward momentum of tragedy, together with the focus of tragedy on errors of judgement made by great men, makes that genre unsuitable for political vision that insists that change is possible (however improbable) if enough "insignificant" people work for it. When we foreclose attempts to imagine different alternatives to war, Woolf seems to say, we foreclose our ability to "think peace into existence" (DETLOFF, 2000, p. 414).

A cena dos espelhos, em que as pessoas da plateia são refletidas, no trecho que se refere ao momento presente, seria uma das mais significativas, pois:

Rather than a unifying vision of British subjecthood, La Trobe's mirroing provides a vision of subjects who are in history consolidated and re-consolidated by the temporal flux of events and ideas - and not simply the inheritors of history (DETLOFF, 2000, p. 408).

Sendo agentes da história e não simplesmente seus herdeiros (e ainda tendo uma mulher na posição de comando), o povo poderia mudar o curso e os resultados dessa história, tornando-a menos violenta. Encarar o presente é assumir a ideia de um futuro que se aproxima. Como serão os próximos minutos, as próximas horas, os próximos dias? Ninguém pode responder: a guerra é iminente. Todos ficam perplexos quanto ao tempo presente, pois até então suas preocupações haviam sido com o passado histórico, com os conflitos diários de qualquer comunidade. Mas e agora? 0 que fazer do futuro? O terror chega na forma de um futuro incerto, que virá logo após o instante presente.

Terminada a peça, quando todos se vão, Mrs. Swithin retoma sua leitura, Outline of History e, novamente, volta à pré-história, ao lugar onde seria a Inglaterra. Isa e o marido, Giles, retomam sua vida de amor e ódio, da qual uma nova vida poderá nascer. E assim, nas últimas frases do romance, mais uma vez remete-se ao início da história e da História: 
Isa let her sewing drop. The great hooded chairs had become enormous. And Giles too. And Isa too against the window. The window was all sky without colour. The house had lost its shelter. It was night before roads were made, or houses. It was the night that dwellers in caves had watched from some place among the rocks.

Then the curtain rose. They spoke (WOOLF, 1992, p. 130).

Com essas palavras, entretanto, um novo ato parece que terá início, como explica Beer: "In those final sentences a new act is set to begin: sexual, theatrical, war-like, yet suggesting continuance" (BEER, 1992, p. x).

Pode-se dizer, ao final desta análise, que Woolf monta uma épica histórica estilhaçada, onde o final apoteótico, ou apocalíptico, se mistura ao seu próprio fim. Sua loucura e a loucura da guerra, da humanidade, são retratadas com rigor na loucura plotless de Between the Acts que, se com relação à História pretende ser um entreato, para a sua história pessoal foi $o$ ato final.

\title{
RESUMO
}

Este trabalho de pesquisa e análise sobre "Between the Acts" (1941), o último romance de Virginia Woolf, pretende demonstrar como a autora, misturando épocas, personagens do passado e do presente, falas e pensamentos, intensifica sua representação do tempo e fluxo da consciência, à medida que tece uma narrativa onde as linguagens verbal e não verbal interagem e compõem seu diagrama escritural.

Palavras-chave: análise literária; Virginia Woolf; fluxo da consciência; iconicidade; diagrama.

\begin{abstract}
This research and analysis paper about "Between the Acts", Virginia Woolf's last novel, aims at showing how the author, mixing epochs, characters from past and present, speeches and thoughts, intensifies her representation of time and the stream of consciousness by creating a narrative where verbal and nonverbal languages interact and so make her scriptural diagram. Keywords: Literary analysis; Virginia Woolf; stream of consciousness; iconicity; diagram.
\end{abstract}


ALVES, S. F. Between The Acts...

\section{REFERÊNCIAS}

BEER, Gillian. Introduction to Between the Acts. London: Penguin, 1992. p. ix-xxxv.

DETLOFF, Madelyn. Thinking Peace into Existence: The Spectacle of History in Between the Acts. [on line]. 2000. Disponível em: < http://instructional1.calstatela.edu/mdetlof/pubs/ thinkingpeace.pdf $>$. Acesso em: 22/04/2001.

LEHMANN, John. Virginia Woolf. Tradução de: Isabel Prado. Rio de Janeiro: Jorge Zahar Editor, 1989. Coleção Vidas Literárias.

SANTAElla, Lucia. Semiótica Aplicada. São Paulo: Pioneira Thomson Learning, 2002.

SANTAELlA, Lucia; NÖTH, Winfred. Imagem: Cognição, Semiótica, Mídia. São Paulo: Iluminuras, 1999.

WOOLF, Virginia. Between the acts. London: Penguin Books, 1992.

Submetido em: 27/06/2008.

Aceito em: 15/09/2009. 